\title{
Usage of Cell Phones by Children: A Qualitative Research in Turkey
}

\section{Banu Karsak, Galatasaray University, Turkey}

\begin{abstract}
The aim of this research is to specify the ways children use cell phones. The research has been conducted with the qualitative research method. The qualitative method, by definition, aims to "qualify" phenomena and studies. In-depth interview method, one of the most effective data collection techniques, was used and focus group discussions were held for this study. In addition, ethnographic observation studies at homes, as well as informal observation studies at schools were carried out with reference to previous research findings asserting that the ways children use cell phones and their daily lives should be studied as a whole.
\end{abstract}

This research, the findings obtained from which are going to be shared in the following pages, is a qualitative study on how children use cell phones. In theory, the observer sociology, the basic foundation of which is mentioned above briefly, was established through a model that takes reception studies and the "uses and gratifications" approach as references. Although not feeding on political economy theories in the overall, the model, at least at a macro scale, takes socio-economic conditions and the context (in order to establish a correlation between media practices, media utilization and the social and economic conditions of both media and the observer) into account.

As to be explained in the "method" section below, the research question and the target population (children between 5-14 years old) were the factors necessitating a qualitative method and ethnographic observations. The primary question intended to be answered in this study is: "what do children do with cell phones?"

This study, like all the researches utilizing the qualitative method, aims to provide a qualitative representation that offers a portrayal as comprehensive as possible, instead of a representation consisting of statistics only. Diversity through a minimum sample size involving various types of conflict and the separation of atypical examples are some of the criteria which are regarded when bringing forward a representation that answers the description above. The sampling characteristic of the research, stated in following, verify that 
our study has succeeded in achieving this objective. The research has been conducted in the centres of 4 cities; which are Istanbul, Ankara, Izmir and Gaziantep.

Standard and strategic parameters were used at the stage of selecting the children to be interviewed. These parameters respectively were gender, age range, socio-economic status of the family, number of siblings, job status of the mother and the qualification of the school children are going to (private school/public school; full-time, half-time).

The children to be interviewed were selected by the research team, representatives from the professional organizations supporting the study and local executives and educators. The "snowball" method, which can be briefly explained as one in which the interviewee is asked to recommend a relative fitting the criteria of the research, was also employed when deemed necessary. Within the scope of the fieldwork in the city centres of Istanbul, Gaziantep, Ankara and Izmir: 25 focus group discussions (154 children in total) 106 in-depth interviews 8 ethnographic observation studies, totalling 268 meetings and interviews have been carried out.

Table 1: SAMPLE DISTRIBUTION

\begin{tabular}{|l|c|c|c|}
\hline CITY & (n) & $\begin{array}{c}\text { 4-9 YEAR } \\
\text { OLDS }\end{array}$ & $\begin{array}{c}\text { 10-14 YEAR } \\
\text { OLDS }\end{array}$ \\
\hline \hline ISTANBUL & $\mathbf{6 3}$ & $\mathbf{3 2}$ & $\mathbf{3 1}$ \\
\hline ANKARA & $\mathbf{5 8}$ & $\mathbf{1 7}$ & $\mathbf{4 1}$ \\
\hline IZMIR & $\mathbf{6 8}$ & $\mathbf{2 8}$ & $\mathbf{4 0}$ \\
\hline GAZIANTEP & $\mathbf{7 8}$ & $\mathbf{4 6}$ & $\mathbf{3 2}$ \\
\hline \hline TOTAL & 268 & 123 & 145 \\
\hline
\end{tabular}

\begin{tabular}{|l|c|c|c|}
\hline SEC & $(\mathrm{n})$ & FEMALE & MALE \\
\hline \hline AB & $\mathbf{1 1 5}$ & $\mathbf{5 2}$ & $\mathbf{6 3}$ \\
\hline C1/C2 & $\mathbf{1 1 0}$ & $\mathbf{6 2}$ & $\mathbf{5 0}$ \\
\hline DE & $\mathbf{4 0}$ & $\mathbf{1 9}$ & $\mathbf{2 2}$ \\
\hline \hline TOTAL & 268 & 133 & 135 \\
\hline
\end{tabular}




\section{Introduction}

The new concept of media involves all mobile communication devices including computer based digital platforms and mobile phones. The changes introduced to communication practices by the information society can be witnessed in a striking way in the utilization of the new media, by children. Using the new media, children can create contents in an online environment, participate in social networks actively, develop their digital game experiences, communicate, make searches and contribute to their education lives. All these varieties in utilization are being analysed under the titles of Mobile Phones/Smart Devices and Computer/Internet utilization.

The rapidly advancing technology has become a part of children's lives just like it has become a part of ours. The mobile phones, in particular, that we can hardly drop, with all their qualities developing each passing day, besides meeting our needs of communication, are also occupying an important place in our lives with their features both entertaining us and rendering access to information possible. As Castelain-Meunier says in the article entitled "Self phones of the students: a paradoxale intimacy tool" the use of self phones is an important point of intersection between public space and private space (2002:233).

In recent years, smart phones have become indispensable devices, especially for the youth. Their familiarity with technology and their predisposition towards them, give the young the opportunity to use all features of these phones efficiently. They are usually using smart phones to communicate, play games or to reach information. Approximately half (46\%) of the children who are between 10-14 years old and have participated in the study, have their own mobile phones. Mobile phones that can be used for a number of activities such as playing games, taking photos, surfing the web and social media, or briefly stated, the smart phones constitute half of this number (19\%). In addition, one fourth (25\%) of the same group, have their own personal computer (Figure 1). 
Table 2 Percentages on having a personal electronic device/on the basis of age

\begin{tabular}{l|c|c|c|} 
& $\begin{array}{c}\text { Total } \\
\text { Average }\end{array}$ & $\begin{array}{c}\text { 10-14 Age } \\
\text { Group }\end{array}$ & $\begin{array}{c}\text { 4-9 Age } \\
\text { Group }\end{array}$ \\
\hline Mobile Phone & $27 \%$ & $46 \%$ & $9 \%$ \\
\hline Personal Computer & $17 \%$ & $25 \%$ & $9 \%$ \\
\hline Smart Phone (iPhone, & $11 \%$ & $19 \%$ & $3 \%$ \\
etc.) & $10 \%$ & $13 \%$ & $6 \%$ \\
\hline iPad /Tablet & $9 \%$ & $11 \%$ & $7 \%$ \\
\hline Portable Computer / & $5 \%$ & $9 \%$ & $1 \%$ \\
\hline Laptop & $5 \%$ & $5 \%$ & $4 \%$ \\
\hline Game Console & $43 \%$ & $23 \%$ & $64 \%$ \\
\hline iPod & & & \\
\hline No Answer & $\mathbf{2 8 2}$ & $\mathbf{1 6 6}$ & $\mathbf{1 1 6}$ \\
\hline
\end{tabular}

\section{Findings}

It has been discovered within the scope of our study that, having a mobile phone is clearly being correlated to age, by the children who participated in our study. In other words, having a mobile phone, from the perspective of children, as reflected in their expressions below, emerges as a symbol of growing, ending of childhood and gaining autonomy (Singly 2000):

"I do not have a mobile phone since I am small. I am a small kid yet." (E, female, 9 years old, public school, C1, 3 siblings, Gaziantep)

Families are buying mobile phones to their children when the child reaches a certain age and a level of maturity. Corinne Martin's research confirms that result. Martin explains that children are always kept their mobile phones in their hands even at nights to feel the vibrations (Martin, 2003).

The words of a 7 year old, "I do not have a mobile phone. Maybe I can have one in middle school" (Ö, 7 years old, male, public school, B, 2 siblings, Izmir) bear out the words of 
another, saying "My mother will buy me one in the $5^{\text {th }}$ grade" (E, female, 9 years old, public school, B, Izmir) and emphasize that from the perspective of children, it is possible to have a mobile phone only at a certain age. On the other hand, some children are of the opinion that the age they can have a mobile phone, corresponds to a certain grade at school. "One does not have a mobile phone in the $3^{\text {rd }}$ grade!" ( $\mathrm{B}$, female, 10 years old, public school, $\mathrm{C} 1$, singleton, Izmir)

However, as a matter of fact, the perception of this 'certain age' is associated with socioeconomical status and therefore with economic conditions, as well as a concept that can be put in the same equation with these, which is the "social circle". A girl continuing her education in a private language immersion school serves as an example for this case.

'I used to have a phone but I do not use it much anymore, now I have an iPod and I am using it more often. (Do any of your friends in the class have a phone?) Everyone in the class, I mean they all have.' (C, female, 10 years old, A, private school, 2 siblings, Istanbul)

Although buying mobile phones to their children, parents see mobile phones as an instrument that children can play with only, or that keeps them 'occupied'. The shared idea of a few 10 year olds who say 'I have a mobile phone but there is no SIM card in it', points out the way parents see mobile phones. (S, Female, 10 years old, private school, 2 siblings, A, Izmir)

\section{Utilization with the Purpose of Communication}

It is possible to name different reasons for using mobile phones with the purpose of communication. For an example from a family with a traditional structure, a child tells that, she is using her mother's phone in order to communicate with her parents, by saying;

'I also use my mother's phone to call my father and Uncle Murat and bless their Friday.' (S, female, 8 years old, public school, C2, 3 siblings, Gaziantep)

For the relatively elder age groups, the children who go to private teaching institutions at weekends to prepare for the tests use mobile phones to communicate with their parents. 
'Sometimes our parents get worried. That is why I am carrying the phone with me. My mother trusts me actually. She still gets worried when I go to or return from classes though.' (S, Male, 11 years old, public school, C1, 2 siblings, Istanbul)

Sending messages is also another way of communicating among the children. A 14 year old child, who considers the mobile phone as a vital part of her life, describes the importance of it with the words: 'It is quite everything to me. I am using it every day. I am sending messages to different people every day. ' $\mathrm{K}$, female, 14 years old, public school, $\mathrm{C}$, singleton, Izmir)

Children who have mobile phones expressed that they use mobile phones in order to communicate with their parents and friends as well as to organize meetings with their friends.

'We go to (a chain café). (She does not stop playing with her mobile phone in the meanwhile) The days I meet with friends I take my phone with me, I do not actually use it very often but I use it to organize meetings with my friends. The teaching institution is quite entertaining. We sometimes go to (Shopping Mall) or to (a chain café) et cetera, after classes. At those times we carry our phones with us. My mother might want to reach me via my mobile phone. (E, female, 14 years old, private school, A, 2 siblings, Istanbul)

Stating that mobile phones help parents track them, some of the children have also remarked that they envy the children of the past eras since they were acting more freely, in the nonexistence of such communication devices.

'Okay but... I heard that it was interesting in the past. My grandmother tells me that they used to skip school... et cetera... Today, the phone starts to ring as soon as you are a few minutes late...' (E, female, 14 years old, private school, A, two siblings, Istanbul)

\section{Using Mobile Devices to Play Games}

Students who are the members of families with average and high income use the media when going to school via service buses and public transport, to listen to music and/or play video games. On the other hand, the children of families in lower SEC groups are unable to use such devices to play games or spend time since it is not very probable for them to have devices like mp3 players or tablets. A student from a low SEC explains the situation as: 
'The reason why we do not play with my father's mobile phone is not that it is forbidden or that we do not like to play with it. I do not know how to put it. It is like we do not want to play with it anyway.' (N, 12 years old, D SEC, public school, 3 siblings, Gaziantep). As for the conditions determined by the parents, it can be seen that the parents do not want their children to install paid games and that they furthermore forbid their children to.

'There are some games available. But they are paid games... I am not allowed to play them. ( $\mathrm{S}$, female, 9 years old, public school, singleton, D, Istanbul)

The words, 'iPhone is the best in the world... It is the best for playing video games', explain the reason why children want to have a mobile phone and that the primary reason of it is to play games. (B, male, 11 years old, public school, singleton, B, Izmir)

\section{Using Mobile Devices to Listen the Music}

Besides occupying an important place in their daily lives, mobile devices occupy an important place in also the education lives of children. Although being forbidden at most schools, it is possible to see children use mobile phones on the way to school or home, with the purpose of listening to music. The words of a 14 years old girl summarize the situation with the words below:

'We listen to music when going to school. Most of the time, I listen to music on my phone. I can take my phone to school with me but I am not allowed to turn it on without permission. So we cannot make a phone call. I keep it turned off at school but we are allowed to use it in the service bus, so we can listen to music with it.' (Z, female, 14 years old, private school, 2 siblings, A, Istanbul).

Another child summarizes the place her mobile device and music occupy in her life, with the words: 'I always listen to music too. I take my earphones and find a silent place. I listen to music while doing my homework and sometimes I listen to music at a low volume when reading a book.' (D, 10 years old, female, public school, C2, 2 siblings, Istanbul). 


\section{Intrafamilial Ownership and Conditions of Using}

The children who do not have their own phones use their parents' phones, under certain restrictions. Children in lower age groups, in particular, are using their parents' phones to play video games. The primary condition under which the children are allowed to use the mobile devices is to install the games that are free to play only.

'I do not have one but my father does and I sometimes use it. Once I had downloaded a game to my elder brother's mobile phone and my father had gotten so angry.' (N, female, 7 years old, public school, C1, 2 siblings, Ankara)

It can be observed among poorer communities that children can use the phones of their parents/elder siblings with different purposes.

'I check the weather forecast on my mother's mobile phone.' (H, 8 years old, male, D, public school, Gaziantep)

Forbidding the child to use the mobile phone shows that, it might result in disciplinary action in some families. A 13 year old clearly expresses that his parents forbid him to use the phone in order to make sure that he is studying harder, especially during the exam weeks, by saying 'No using the phone during the exam weeks!' (M, male, 13 years old, public school, D, 2 siblings, Izmir)

However, depending on the economic standards of the family, these rules might as well be a reflection of the measures taken by the family in order to prevent 'possible damages'. The elder daughter of a middle-class family who was interviewed within the scope of our ethnographic observation study in Izmir points out to this case, saying 'They do not let me touch it. My sibling had once pressed a button of my mother's phone and had accidentally called our father 15 times or so... They also say that it might break.' (7 years old, public school, 2 siblings)

Utilization of mobile phones and other electronic devices also emerge as an element of intrafamilial conflict. The sentences below can be helpful in exemplifying the said case. 
'My mother smacks me in the head and then she feels sorry for doing so, but that is when I make her angry... She tells me to get off the computer but I do not and then she gets angry. She once forbade my elder sister to use the computer for a week and she also forbade her to play with her mobile phone... It made my sister cry in anger.' (Y, 13 years old, public school, B, 2 siblings, Istanbul)

Another child remarks that the aim of these rules and restrictions is to motivate children to study, with the words: 'Tells me to drop the phone and study... Or to turn the computer off and read a book instead... My mother gets even angrier when she is nervous.' (E, 14 years old, female, private school, A, 1 sister, Istanbul)

It has been observed that the children of families with average and high income use mobile phones but that some families limit their children about using their mobile phone.

'It is possible to buy credits. You can buy credits to send messages and it is affordable but my mother does not allow me to buy it. They say 'all you have to call is us, what would you need the credits for, anyway.' (Ç, 14 years old, male, public school, A, singleton, Izmir)

In terms of their technology skills, children, besides adapting to using mobile phones faster than their parents do, also guide them in adapting to the technology. The 13 years old child guiding his parents in using mobile phones sheds light on the situation with the words, 'I use mobile phones but sometimes when they get confused, they ask me to show them how to do the things they want to do.' (B, 13 years old, male, public school, B, 2 siblings, Izmir)

\section{Conclusion}

The new media, from the perspective of the children who are unable to own it or to have access to it, is a centre of attraction, or even a goal. Since having a mobile phone, in particular, is correlated to age or growing, by the children, it would not be wrong to call it the modern 'ritual of adolescence'. The priority of both mobile phones and Internet in the perspective of children, which they attribute to the "game" function, is a finding that should be taken into consideration. 
It can be seen that, the children who have the opportunity to access, turn computer and Internet into a part of their domestic, education and social lives and that they even start to develop different ways of using them, beginning from the early ages. To put it more explicitly, it was observed that some of the children, who can easily have access, even approach the situation from a critical perspective and limit the time they spend on the media, through self-control.

It has been ascertained that no audio-visual materials, except the basic tools, are being used in a majority of the public schools. It is also observed that employment of technology in these institutions could be rendered possible only in consequence of the personal initiatives of the teachers and by means of their (own) personal hardware.

It can be seen that parents, educational institutions and teachers have been adopting the same manner in making certain regulations and setting rules and restrictions on using the media. With this regard, the restrictions on using mobile phones and personal computers or smart devices at schools, aim to encourage children to participate in traditional kid games, informal sports activities or to spend time with others during the recess. Besides giving those who cannot regularly participate in the sports activities the opportunity to involve, this approach also plays the determining role in helping the children to build bridges with their peers and in promoting socialization.

It can be understood by means of this study that, the rules and restrictions determined by the parents or other adults, on children's access to media, is a matter that rather focuses on 'school/homework' and a method employed to limit the time children are allowed to spend on it. Limits and restrictions on contents, on the other hand, are not that much. The reason of this, especially regarding the TV programmes, can be associated to the rules determined by the regulatory body on contents, target audience and airing times, that are considered to be 'satisfactory' by the families. However, what we have witnessed during the field works have shown that the bans imposed to television programmes can easily be flouted by the children, or in other words, that, strict limitations might not always result as expected, but sometimes $\mathrm{v}$ ök1 might also result in adversity. 


\section{Acknowledgement}

This paper has been financially supported by Galatasaray University Research Fund under Grant no 16.300.004.

\section{References}

Castelain-Meunier Christine, Le téléphone portable des étudiants:un outil d'intimité paradoxale, Réseaux, no 116, 2002.

Martin Corin, Téléphones portables chez les jeunes adolescents et leurs parents: quelle legitimation des usages?, 2eme workshop de Marsouin, Bretagne, 2003.

Singly de F, Libres ensemble: L'invidualisme dans la vie commune, Paris, Nathan, 2000.

Çocukların Medyayı Alımlama ve Kullanım Biçimleri Araştırması, Galatasaray University, MEDIAR, 2014. 